\title{
Redefinition of the Terminus of the Middle America Trench
}

\author{
Román Alvarez \\ Instituto de Investigaciones en Matemáticas Aplicadas y en Sistemas, Universidad Nacional Autónoma de México, \\ Ciudad Universitaria, México DF, México \\ Email: Roman.alvarez@iimas.unam.mx
}

Received March 4, 2013; revised April 6, 2013; accepted May 3, 2013

Copyright (C 2013 Román Alvarez. This is an open access article distributed under the Creative Commons Attribution License, which permits unrestricted use, distribution, and reproduction in any medium, provided the original work is properly cited.

\begin{abstract}
The terminus of the Middle America Trench has been traditionally represented as an arc, concave towards the continent. Tres Marías Islands are located at the terminus of the Middle America Trench in western Mexico, and their location is not only intriguing but also a key to the re-construction of the position of Baja California peninsula before separation from the North America plate. Previous re-constructions suggested various places around the location of Tres Marías Islands for the position of the tip of the peninsula, and several converge to a position that invades the area occupied by the islands, offering no explanation for the overlap. Before peninsular separation from North America, the Guadalupe trench followed a smooth curve; recreating the position of this paleo-trench yields a baseline for fixing the position of the peninsula, as well as the original position of the Tres Marías Islands fragment. A new tectonic view of the structure of the Middle America Trench terminus is proposed, replacing the traditional arc representation with a series of en echelon blocks, the northernmost terminates at the Tres Marías Escarpment. The long sides of the blocks correspond to previously identified geological faults in the Bahía de Banderas region, while their offshore continuation is supported by topographic observations. As a test of this model I show the corresponding re-construction of the position of Baja California prior to separation from the North America plate and the positional evolution of the peninsula and the Tres Marías fragment from Chron 4n.2 (7.90 Ma) to Chron 3n.4 (5.12 Ma).
\end{abstract}

Keywords: Middle America Trench; Tres Marías Islands; Guadalupe Trench; MAT Terminus; Banderas Fault

\section{Introduction}

Several inferred positions of Baja California (BC) before detachment from the North America plate (NAM), locate the peninsula overlapping the space where Tres Marías Islands (TMI) are located at present [1,2], while others place it at different surrounding locations [3-5]. The Middle America Trench (MAT) extends from Central America throughout the western coast of Mexico and terminates at the Tres Marías Islands; it involves the Cocos and Rivera plates and follows a general NW trend. At around latitude $19.35^{\circ} \mathrm{N}$ this trend changes to an arc that turns gently to the $\mathrm{N}$ terminating at the base of the Tres Marías Escarpment (TME). This has been the traditional representation of the terminus of the MAT [6,7] and all maps available depict it that way. A re-construction of plates and plate boundaries [8] from 15 to 3.5 Ma shows the Guadalupe plate at $15 \mathrm{Ma}$ as a single plate from Guadalupe Island to south of the Clipperton and Tehuantepec fracture zones, enclosing the Cocos, Rivera, and a por- tion of the present Pacific plates. At that time the Guadalupe trench (the joint Middle America and North America trenches) was continuous, although somewhat deformed, across the mouth of the Proto-Gulf of California. At 9 Ma the Rivera plate extended down to the Orozco Fracture Zone and the Tosco-Abreojos fault replaced the abandoned trench west of $\mathrm{BC}$ as the limit between the Pacific and NAM plates, while the terminus of the MAT was already displaced from its location at the continuous trench and ending at the TME. In this re-construction the tip of the peninsula was located $\sim 200 \mathrm{~km}$ NW of TMI. The Proto-Gulf of California was described as a broad volcano-tectonic rift zone created by an extensional mechanism that preceded the separation of Baja California from the NAM plate [1].

Another re-construction of the position of Baja California to $5.5 \mathrm{Ma}$ was made [3] translating it $300 \mathrm{~km}$ back along the $124^{\circ}$ azimuth of the major fracture zones. They found that the $1000-\mathrm{m}$ isobath nearly abuts that north of the Tres Marías block, and that the escarpment that marks 
the edge of the continental crust fits exactly the curve of the base of the Tres Marías Escarpment, implicating the earlier proximity of these structures. Other re-constructions have used this translation of BC to the SE, which presumably closed the Gulf at around 5.5 Ma [4,9,10]. However, still another re-construction [5] performed the same exercise arriving at nearly the same position while arguing against a complete closure of the Gulf under such a translation, placing the peninsular continental limit at a short distance west of TMI. This right-lateral displacement of $300 \mathrm{~km}$ is well documented on the southern part of the San Andreas Fault system and Gulf transform faults [11-13] and is attributed to post 6 Ma motion of the peninsula. In summary, some authors [14,15] place BC north of TMI, others [16] favor its early location nearby Banderas Bay, and some others [3] place it south of Banderas Bay. However, in the context of the re-constructions, the above studies do not directly address the location of TMI at that time.

\section{The Continuous Trench}

Guadalupe trench was continuous until the separation of Baja California from NAM began. The limit between the abandoned and active trenches apparently defined the rupture line between them; to the NW of that point (BC) the trench was abandoned, while to the SE (mainland Mexico) the trench remained active. These conditions of the trench remain to the present but the abandoned trench and the active one are now separated $\sim 500 \mathrm{~km}$. Additionally the active trench was deformed from its position at the time of rupture, while the abandoned trench preserved its form. In order to recover the position of the terminus of the MAT at the time of break up the first task is to propose a path for the continuous trench in order to use it as a reference re-construction line. At Chron 6.0 (20 $\mathrm{Ma})$ the trench traced a smooth curve from Vancouver, Canada to Manzanillo, Mexico [17] and there is no indication of substantial location changes until 5.0 Ma. Figure 1 shows a portion of the abandoned trench west of

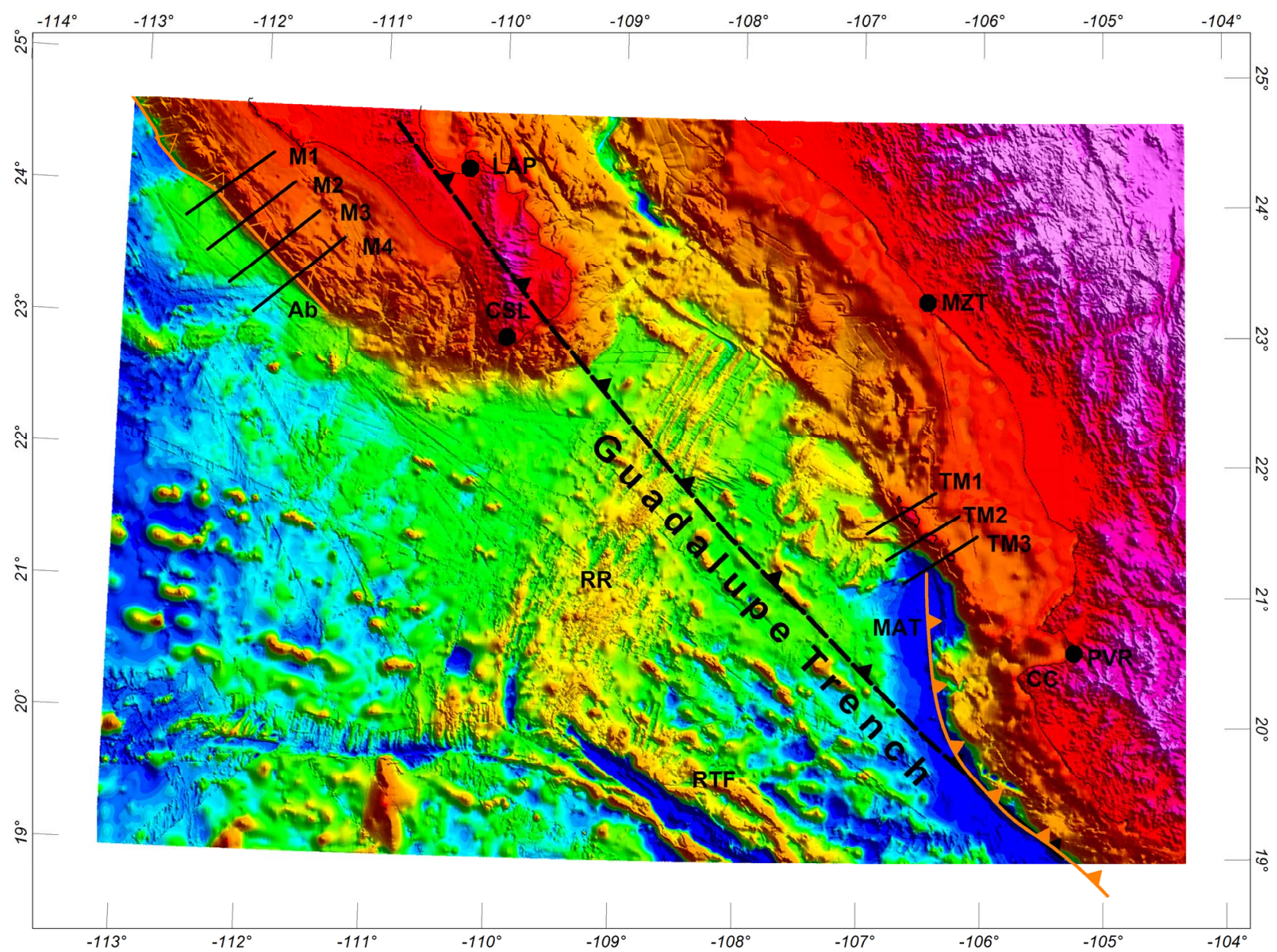

Figure 1. Past and present trenches in western Mexico: the abandoned trench (Ab) west of Baja California, the trace of the proposed, reconstructed, Guadalupe trench, and the terminus of the MAT as traditionally represented. Lines M1-M4 and TM1-TM3 locate the corresponding topographic profiles shown in Figure 7. RR Rivera Rise, RTF Rivera Transform Fault, CSL Cabo San Lucas, LAP La Paz, MZT Mazatlán, PVR Puerto Vallarta, CC Cabo Corrientes. Topography from the Global Multi-Resolution Topography (www.marine-geo.com). 
Baja California, the trace of the proposed, reconstructed, continuous, Guadalupe trench, and the trace of the terminus of the MAT as usually represented. One implication of this representation of the MAT is that it favors the collision of neighboring sectors of the subducting slab, which would locally increase seismicity; instead, a marked reduction of seismic activity is observed in the area [18].

Re-construction of the continuous trench is performed by smooth extrapolation towards the NW, of the presently active trench SE of latitude $19.35^{\circ}$, with a second- degree curve that fits the trace of that portion. The constraints for the translation of Baja California to its position at Chron 4n.2 are: 1) that the present, abandoned trench coincides with the trace of the Guadalupe trench upon translation, and 2) that the abandoned and active trenches lay along the trace of that trench as close to each other as possible (i.e., not overlapping). Under such conditions the translation of $\mathrm{BC}$ is $\sim 500 \mathrm{~km}$ in the SE direction (Figure 2), coinciding closely with previous re-constructions [2,9] that did not attempt to explain the presence of TMI.

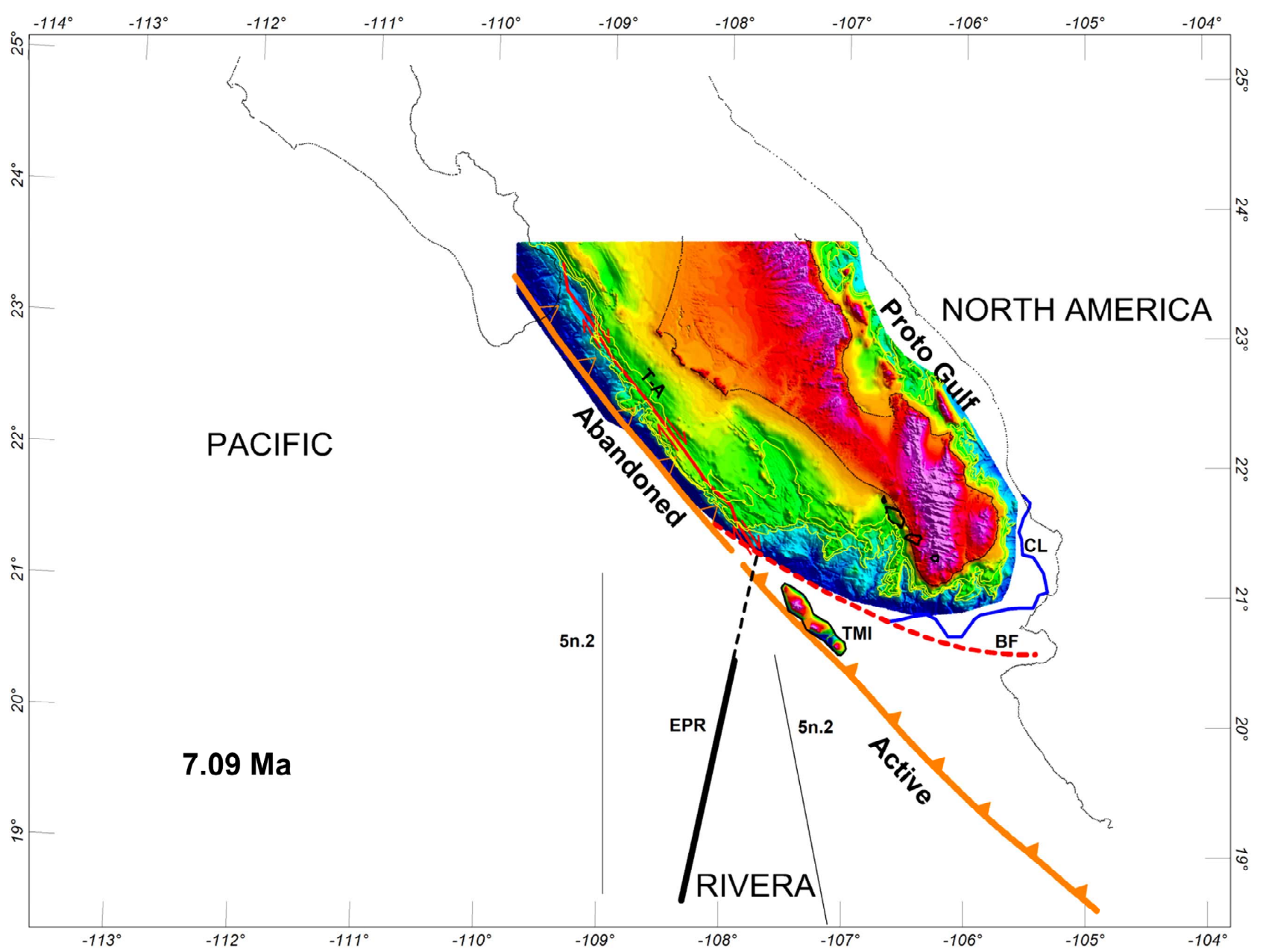

Figure 2. Palinspastic re-construction of BC to Chron 4n.2, when the Guadalupe trench was still continuous and subduction had stopped west of BC. Open triangles indicate the abandoned portion of the trench. The Tosco-Abreojos (T-A) fault was in place. The assumption is made that this was the time when BC began to separate from NAM. TresMarías Islands are shown as part of the continental shelf at that time, as proposed in here. The continental limit (CL) laid fairly close to the coast of Nayarit. Waters from the Pacific Ocean could feed the Proto-Gulf through a $50-\mathbf{k m}$ wide sound (the Nayarit sound) between the coasts of Nayarit and BC. The dashed, red curve joining Banderas fault (BF) and the abandoned trench marks the path of a proposed channel (the Tosco-Abreojos-Banderas, T-A-B, channel) dividing BC to the north and TMI to the south. The channel may have started its development at $\sim 14 \mathrm{Ma}$, when the Magdalena fan and Banderas fault began to form. This channel was probably the conduit to transport the eroded materials from the shelf to the trench, forming the Magdalena fan $[14,25]$. Isobaths for depths of 1000,750 , and $500 \mathrm{~m}$ (yellow) enhance the erosional imprint on the Magdalena shelf, west and south of the tip of the peninsula. The position of the EPR and that of Chron $5 n .2$, the oldest Chron recorded on the Rivera plate, are shown for reference, as well as the perimeter of the Present position of TMI. Extension to the north of the trace of the EPR coincides with the terminus of the T-A fault and the trace of the proposed T-A-B channel. 


\section{Tres Marías Islands Displacement}

Herein I propose that at Chron 4n.2 Tres Marías islands occupied the position shown in Figure 2; they were part of the continental shelf and submerged. The following re-constructions span the period from 7.90 Ma to the Present. The general tectonic scenario at Chron 4n.2 was as follows. The Tosco-Abreojos fault (T-A F) was in place [19], constituting the limit between the Pacific and North America plates and right-lateral shear was acting across this fault. The position of the EPR at that time [20] referred to fixed NAM is also shown, as well as the position of Chron 5n.2, the oldest Chron (9.92 Ma) recorded in the Rivera plate, whose displacement evolution is an important reference in this re-construction. The topography of the islands is also shown for reference although they were submerged at that time; the perimeter of the present location of TMI is shown here and in subsequent figures as a reference. Major topographic trends indicate the existence of a sound between Bahía de Banderas and the peninsular territory, which would have allowed the connection of Pacific waters with the Proto-Gulf of California [1].

The continental limit (CL) of BC as defined in [21] extends beyond the peninsula (blue line around its tip) and lay fairly close to the present coast of Nayarit. The continental limit of the peninsula continued along the red, dashed line joining the Tosco-Abreojos fault, the abandoned trench, and Banderas fault. In [1] a similar line was inferred to exist at $10 \mathrm{Ma}$ linking Bahía de Banderas with the trench south of Cabo San Lucas, while in [8] the Tosco-Abreojos fault was speculated to connect with the MAT south of ITM at $9 \mathrm{Ma}$. This line limits the continental shelf of BC to the north, and the TMI region to the south suggesting the existence of a channel. It terminates at the boundary between the reconstructed active and abandoned portions of the Guadalupe trench, connecting smoothly with the trace of Banderas fault as illustrated in the figure, and considered together they may have constituted a left-lateral shear system (Tosco-Abreojos-Banderas, T-A-B, shear system) along which $\mathrm{BC}$ began to separate from NAM.

The origin of Banderas fault was estimated at $14 \mathrm{Ma}$ $[22,23]$ making it contemporaneous with the Magdalena fan formation. The formation of the Magdalena fan was estimated to take place between 14 and $12 \mathrm{Ma}$, e.g., [24]; however, the precise mechanism of formation is still a matter of debate $[25,26]$ and will be addressed in a separate paper. It is likely that the T-A-B shear system was active at that time. Present evidence of this channel is lacking since the shear system was progressively destroyed when the Tres Marías fragment began to displace northeasterly, as will be shown below. The continental (Magdalena) platform of BC facing this line shows clear signs of erosion all along this limit, enhanced by the irregular isobath shapes at 1000,750 and $500 \mathrm{~m}$ depth (yellow), contrasting with the continental shelf further north that does not show such signs. This observation can provide a clue to the origin of the Magdalena fan since erosional denudation of the Magdalena shelf could have been channeled along this corridor, towards the trench, forming the fan. This is in agreement with a recent estimate [25] of dextral slip displacement of the fan along the trench of $<150 \mathrm{~km}$ as well as with excellent matches of 120 - 65 Ma detrital zircons of the fan, and those of the Magdalena shelf. In this re-construction the ToscoAbreojos fault ends at the intersection with the trace of the T-A-B shear system. Since the NE extension of the EPR also reaches this intersection (dotted line) it suggests that when the EPR advanced northwards it may have created a Ridge-Transform-Trench triple junction, coinciding with previous descriptions of the location of such a point just after the Middle Miocene reorganization, e.g., $[24,27,28]$.

\subsection{Chron $4 n .2$}

The assumption is made that $\mathrm{BC}$ started to migrate towards the NW at the time of Chron 4n.2; the active trench thrusted against the TMI block displacing it to the $\mathrm{NE}$, and the active trench began to deform. The NW displacement of BC from the position at 7.90 Ma to the position at $6.73 \mathrm{Ma}$ was $63 \mathrm{~km}$ at a rate of $54 \mathrm{~mm} / \mathrm{yr}$, while the NE translation of Islas Tres Marías was $17.5 \mathrm{~km}$ at a rate of $15 \mathrm{~mm} / \mathrm{yr}$ in 1.17 My (Figure 3). The BC displacement is obtained from the displacement calculated in [20] of a point in the Rivera plate between Chrons 4n.2 and 3A.2 for fixed NAM. The restriction is that, in its translation to the NE, the position of the islands does not overlap the continental region of southern Baja California. The peninsula and the Tres Marías block sled past another along the T-A-B shear zone and the T-A fault was the boundary between the Pacific and NAM plates. As the active trench thrusted against the TMI block displacing it, the first fault with right lateral motion appeared on the SE side of the TMI block. A portion of the northwestern end of the T-A-B shear zone was destroyed by the advancing Tres Marías block and was probably substituted by a left lateral fault that connected the T-A fault with TMI. The Rivera plate occupied a small sector as indicated by the position of Chron 5 n.2 east and west of the EPR. The positions of the EPR and the eastern branch of Chron 5n.2 were approaching the trench.

\subsection{0 Ma}

An intermediate position between Chrons 3A.2 and 3n.4 at 6.0 Ma is shown, where BC had retreated further (Figure 4) and the TMI block continued advancing north- 
easterly to its new position. The left-lateral fault connecting the T-A fault with TMI grew larger. Along the active trench new right-lateral faults developed and an additional portion of the T-A-B shear system was destroyed. In this figure the positions of the EPR and Chron $5 n .2$ are inferred from those corresponding to Chrons 3A.2 and 3n.4 [20]. The trace of the traditional representation of the trench terminus is shown dashed for reference (MAT-P).

\subsection{Chron 3A.2}

At 5.12 Ma the EPR had penetrated the mouth of the Gulf (Figure 5) and a small segment (MR), the María Magdalena rise, was emplaced close to TMI [20,34]. TMI advanced to the position shown and the terminus of the trench was in touch with the tip of the MR. Another portion of the T-A-B shear zone was destroyed by the advancing TMI block leaving Banderas fault quite close to its present extension. Additional displacement blocks developed further to the SE, accommodated by right lateral displacements; dashed lines in that region indicate where additional faults would form subsequently. The motion of the Rivera plate was analyzed in [20]; displacement paths for points on the Rivera plate relative to NAM were reconstructed showing four paths of points between $17^{\circ} \mathrm{N}$ and $22^{\circ} \mathrm{N}$ in the period between 9.9 to 0 Ma. The four tracks follow NE trajectories of motion from 9.9 to 5.1 Ma. Figure 5 shows arrows labeled d corresponding to the motion of points in those positions between 9.9 and 5.12 Ma [20]. Although the trajectories are somewhat oblique to those proposed for the displaced blocks, the general trend coincides. A $30^{\circ}$ change in orientation of Banderas fault and the axis of Banderas Valley, the continuation inland of Bahía de Banderas, was

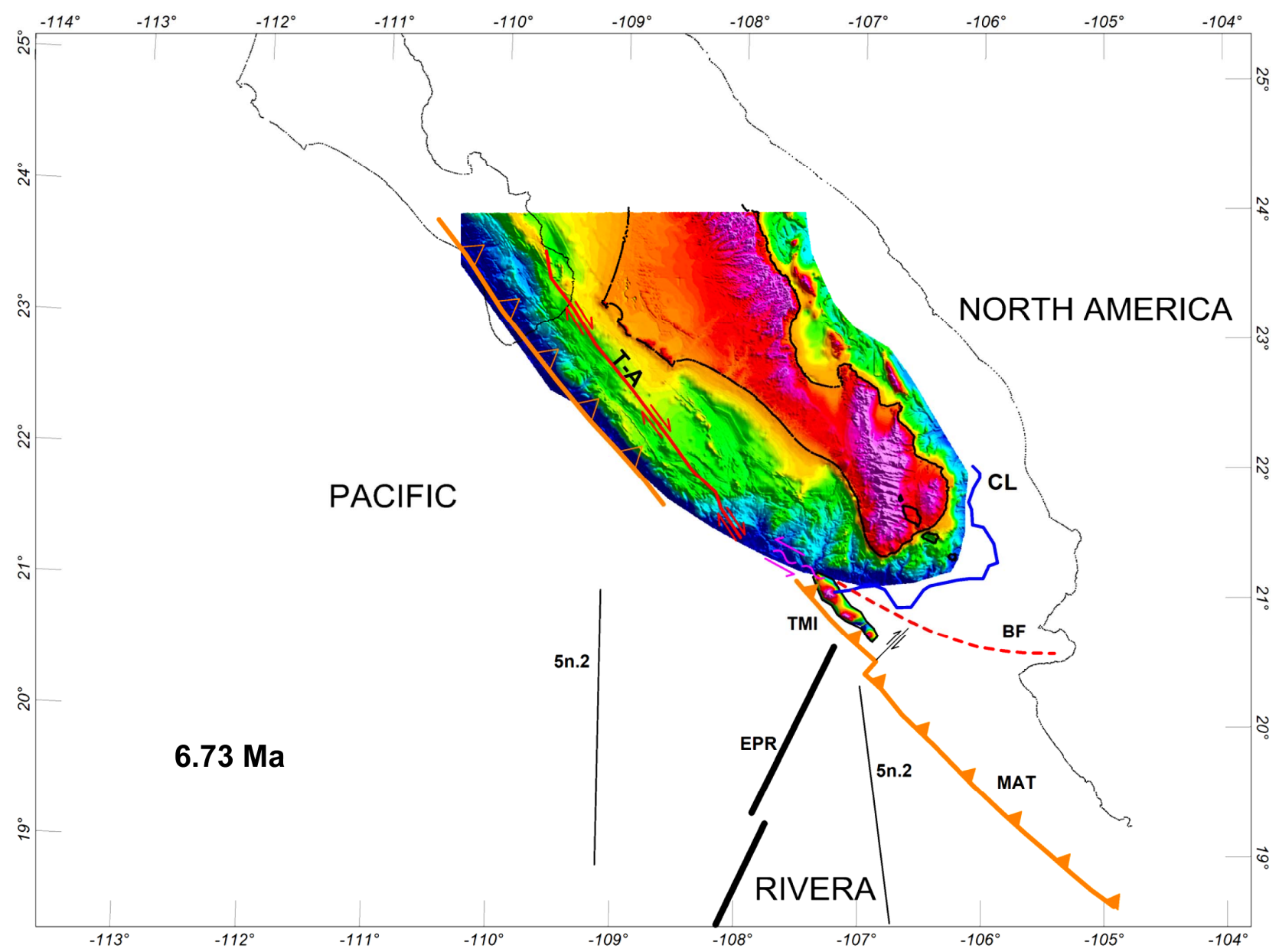

Figure 3. Positions of Baja California and Tres Marías Islands at Chron 3A.2. BC and TMI sled past another along the Tosco-Abreojos-Banderas channel. The NW displacement of BC from the position at 7.90 Ma to the position at $6.73 \mathrm{Ma}$ was $63 \mathrm{~km}$ at a rate of $54 \mathrm{~mm} / \mathrm{yr}$, while the NE translation of Islas Tres Marías was $17.5 \mathrm{~km}$ at a rate of $15 \mathrm{~mm} / \mathrm{yr}$ in $1.17 \mathrm{My}$. Starting at 7.90 Ma part of this channel was destroyed by the advancing active trench and TMI block. The destroyed portion may have been substituted by a left-lateral shear zone joining TMI with the terminus of the T-A fault. The first right-lateral fault appeared SE of TMI and the deformation of the active trench began. The positions of the EPR and Chron $5 n .2$ approached the trench. 


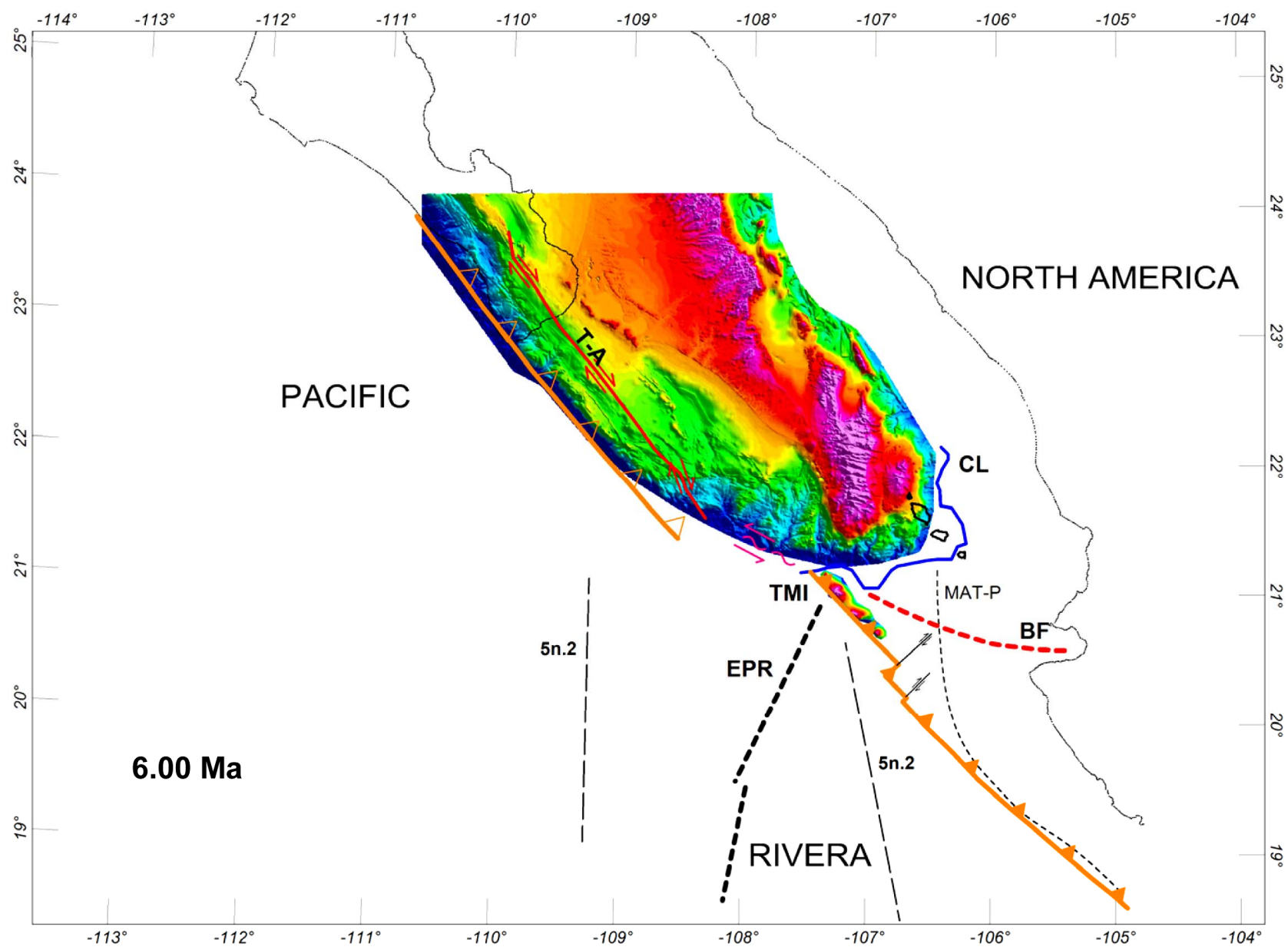

Figure 4. Positions at 6.0 Ma of BC and TMI between Chrons 3A.2 and 3n.4. The EPR and the terminus of the active trench were in contact or very close, creating a region of oblique subduction. Additional right-lateral faults appeared along the active trench and another portion of the T-A-B channel was destroyed. The traditional trace of the terminus of the MAT (MAT-P) is shown for reference. The positions of the EPR and Chron $5 n .2$ (dashed) are inferred from those of Chrons $3 A .2$ and 3n.4.

noted [29] and attributed to an extensional process estimated to initiate at $\sim 5 \mathrm{Ma}$ [23]. Thus, this change in orientation apparently occurred contemporaneously with the initiation of displacement of the easternmost blocks at the trench suggesting a causal effect between them. If extended northwesterly, the small transform fault linking the MR and the main body of the EPR continued along the proposed left-lateral shear zone, connecting with the terminus of the T-A fault, suggesting this line probably represented the limit between the Pacific and NAM plates at that moment. At this time the boundary between the Pacific and NAM plates was about to be transferred to the interior of the Gulf.

\section{The Fault System}

Figure 6 shows the Present position of the TMI fragment including the vicinity of the terminus of the trench divided in sectors. Some of these sectors penetrate Bahía de Banderas (BB), the $60 \mathrm{~km}$ incision of the continent that was proposed as the NW limit of the Jalisco block [29], and coincide with previously identified faults in and around the bay $[22,23,30]$ : Cucharitas-Pitillal fault (CPF), Cabo Corrientes-Bucerías-El Colomo fault (CCBCF), Marietas-Punta Mita fault (MPMF), and Corbeteña fault (CF). This indicates that the normal faults previously identified inland continue offshore, which is corroborated in various places by topographic profiles. However, additional faults not previously identified are spread offshore to the NW, reaching to the TME: El Bajo fault, (EBF), No Name fault (NNF), and María Magdalena fault (MMF). Preliminary, gravimetric and aeromagnetic modeling suggests they are also transcurrent, normal faults (article in preparation). In this interpretation, the terminus of the trench consists of a series of former continental shelf blocks that have been displaced towards the NE from their original positions along the Guadalupe trench. The amount of NE displacement of these blocks 


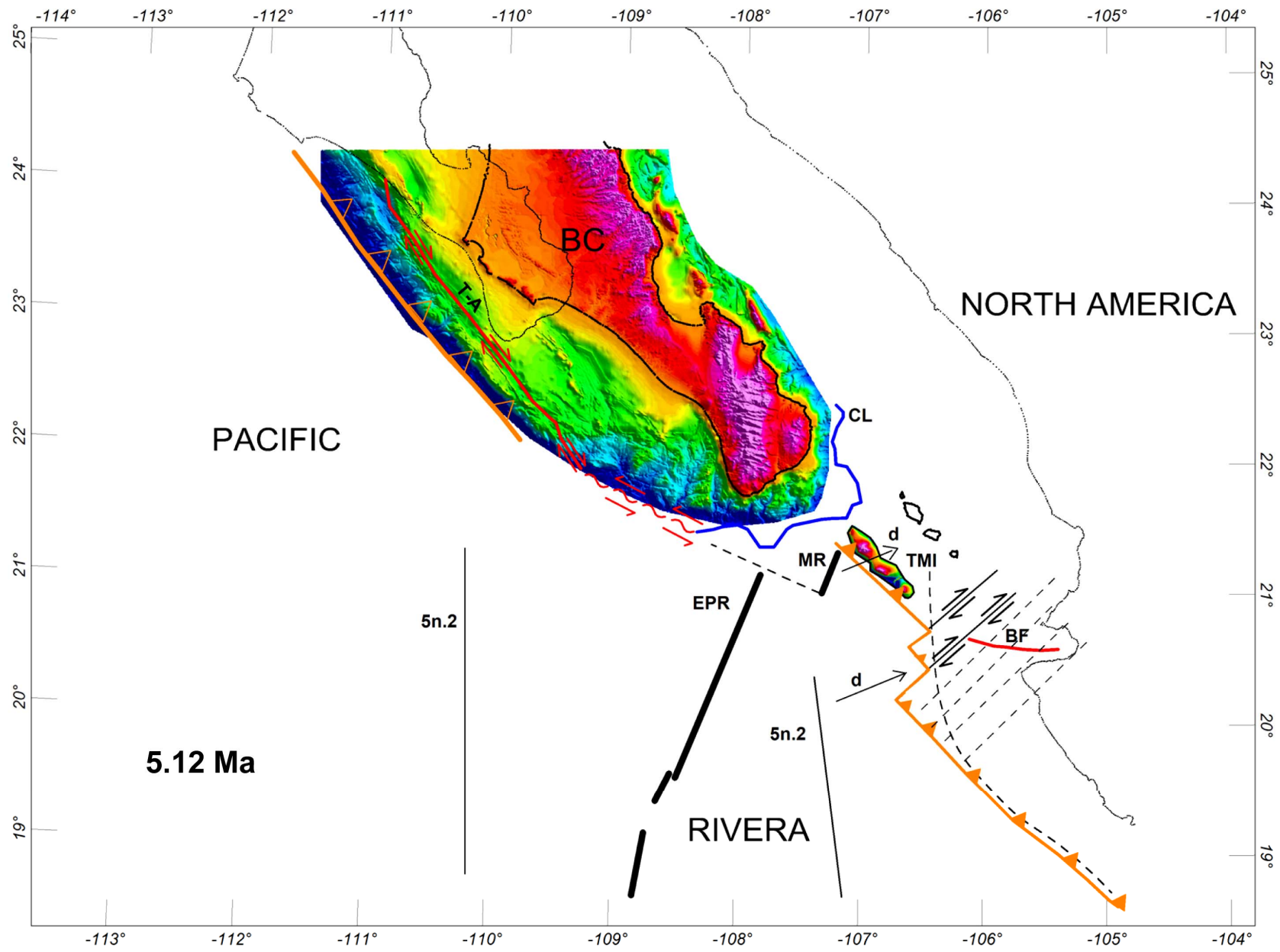

Figure 5. Positions of BC and TMI at Chron 3n.4. The continental limit of BC was clear of the trajectory of TMI and the right-lateral faults SE of TMI grew larger displacing the blocks further to the NE. Dashed lines indicate the places where additional faults would appear subsequently. The EPR jumped to the right creating the Magdalena Rift (MR). The northern end of the MR remained in contact with the terminus of the active trench. The extension to the NW of the small transform fault between MR and the EPR is aligned with the proposed shear zone and the terminus of the T-A fault suggesting this could be the transitional Pacific-NAM limit at that time. The two arrows labeled $\mathrm{d}$ correspond to the direction and displacement of points in those regions between 7.90 and 5.12 Ma calculated in [20]; they show similar trends as those of the block motions proposed in here.

by thrusting decreases from TMI, where it reaches 106 $\mathrm{km}$, to south of Cabo Corrientes; the process advanced southeasterly affecting trench sectors progressively. The position at present of points belonging to Chron $5 n .2$ [20] are shown for reference.

\section{Emergence of TMI}

Geologically the basement of the islands is a granitic complex probably of Upper Cretaceous age covered in places by extrusive rocks of rhyolitic composition, deposited by volcanism during the Eocene-Early Oligocene. In addition, the three islands show accumulations of clays and sandstones of marine origin of Late Oligocene age; according to [31] the largest measured one is 1300 $\mathrm{m}$ thick. The implication is that the islands remained be- low sea level for at least a few million years. After deposition thrusting of the active portion of the MAT may have uplifted the continental shelf above sea level creating the islands, placing their present highest point at $\sim 700 \mathrm{~m}$ above sea level. The topographic profiles along the Magdalena shelf (M1-M4) and along the Tres Marías Escarpment (TM1-TM3) located in Figure 1 are shown in Figure 7. The topographic similitude between the two groups is evident, supporting the assumption that they were shelf neighbors at the beginning of BC separation from NAM. Profiles TM1-TM3 across the Tres Marías Escarpment show the warping and uplifting effects. Warping of the TMI block has been suggested [6] since the block deepens landward, contrasting with the nearly horizontal shelf, thus supporting the uplifting process. A natural candidate for inducing the uplift is the thrusting 


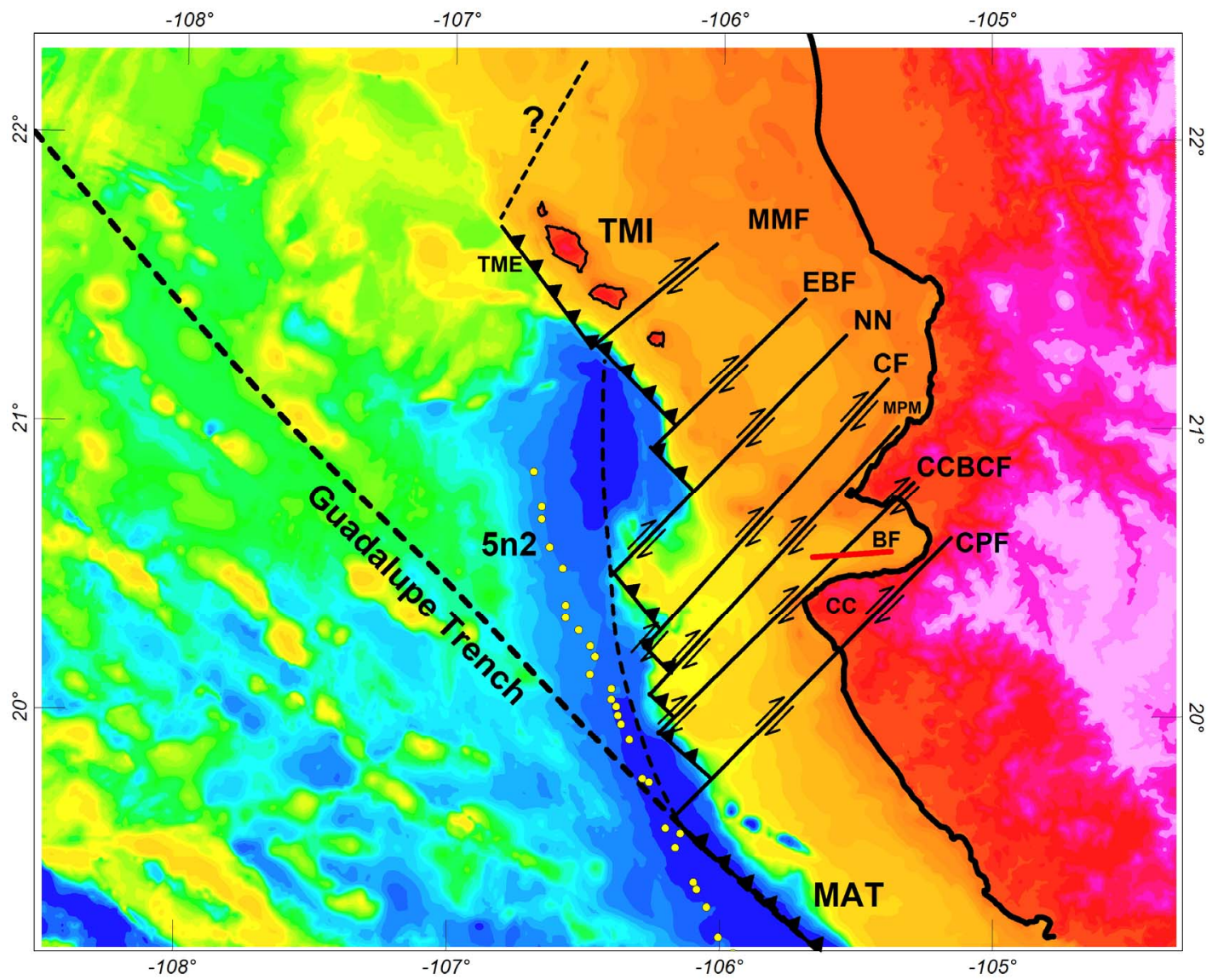

Figure 6. Present status of the terminus of the MAT according to this work. A group of sectors, landwards from the trench, show the proposed tectonic interpretation of the area. The trace of the terminus of the MAT, as in Figure 1, is shown for reference. The subducting oceanic plate thrusted against these sectors since $7.90 \mathrm{Ma}$, displacing them from their original positions along the Guadalupe trench to the places occupied at present. Right-lateral translations (arrows) occur along the faults, reaching $\sim 106 \mathrm{~km}$ at the TMI sector and decreasing displacements from north to south. The yellow dots are points of isochron $5 \mathrm{n} .2$ (9.92 Ma) at their present position. Several faults were previously identified in the area [22,23,29,30]: BF Banderas fault, CPF Cucharitas-Pitillal fault, CCBCF Cabo Corrientes-Bucerías-El Colomo fault, CF Corbeteña fault. Others are being defined by gravimetric and magnetometric means: NNF No Name fault, EBF El Bajo fault, MMF María Magdalena fault.

of the slab against the en echelon blocks; however, other tectonic processes may also be involved. A depth profile along the deflected trench shows a $1000-\mathrm{m}$ bulge along the proposed thrust region: from $4600 \mathrm{~m}$ depth at $(20.19 \mathrm{~N}$, $105.95 \mathrm{~W})$ to $3600 \mathrm{~m}$ at $(20.19 \mathrm{~N}, 106.55 \mathrm{~W})$ back to 4240 $\mathrm{m}$ at $(21.16 \mathrm{~N}, 106.48 \mathrm{~W})$ close to the terminus. At present it is not clear that this bulge can be attributed to the thrusting effect, or to the accumulation of detritus in that region, or both. An anomalous structure (Banderas Mount, $20.60 \mathrm{~N}, 106.30 \mathrm{~W}$ ) in the mouth of Bahía de Banderas [23], consisting of a topographic high that raises abruptly $1600 \mathrm{~m}$ from the depth of the trench is probably a remnant of the eroded shelf; however, with the available information this cannot yet be confirmed.

In addition, the region between the former continuous trench and the TME has high heat flow values [32], which suggests the proximity of a large heat source, corresponding to an area of anomalous exposure of the oce- anic slab, where the sediment accumulation is quite low. The seismological interpretation of a line from Baja California to Bahía de Banderas [33] shows a thin crust $(<10 \mathrm{~km})$ in the TME area, thus placing the upper mantle close to the surface, supporting the presence of a shallow, robust heat source in the area. The geothermal flux in the area is several times the worldwide mean [34], and was proposed that it might be associated with mantle convection currents. In addition, the torque exerted by slab pull on the young and hot oceanic plate is minimal or counterbalanced by forces that resist its motion [20]. A potential explanation may be that the young, hot, and buoyant oceanic plate, being unable to subduct, remained instead close to the surface, thrusting the continental shelf displacing, warping, and uplifting it.

\section{Conclusion}

When the north portion of the Guadalupe trench was 


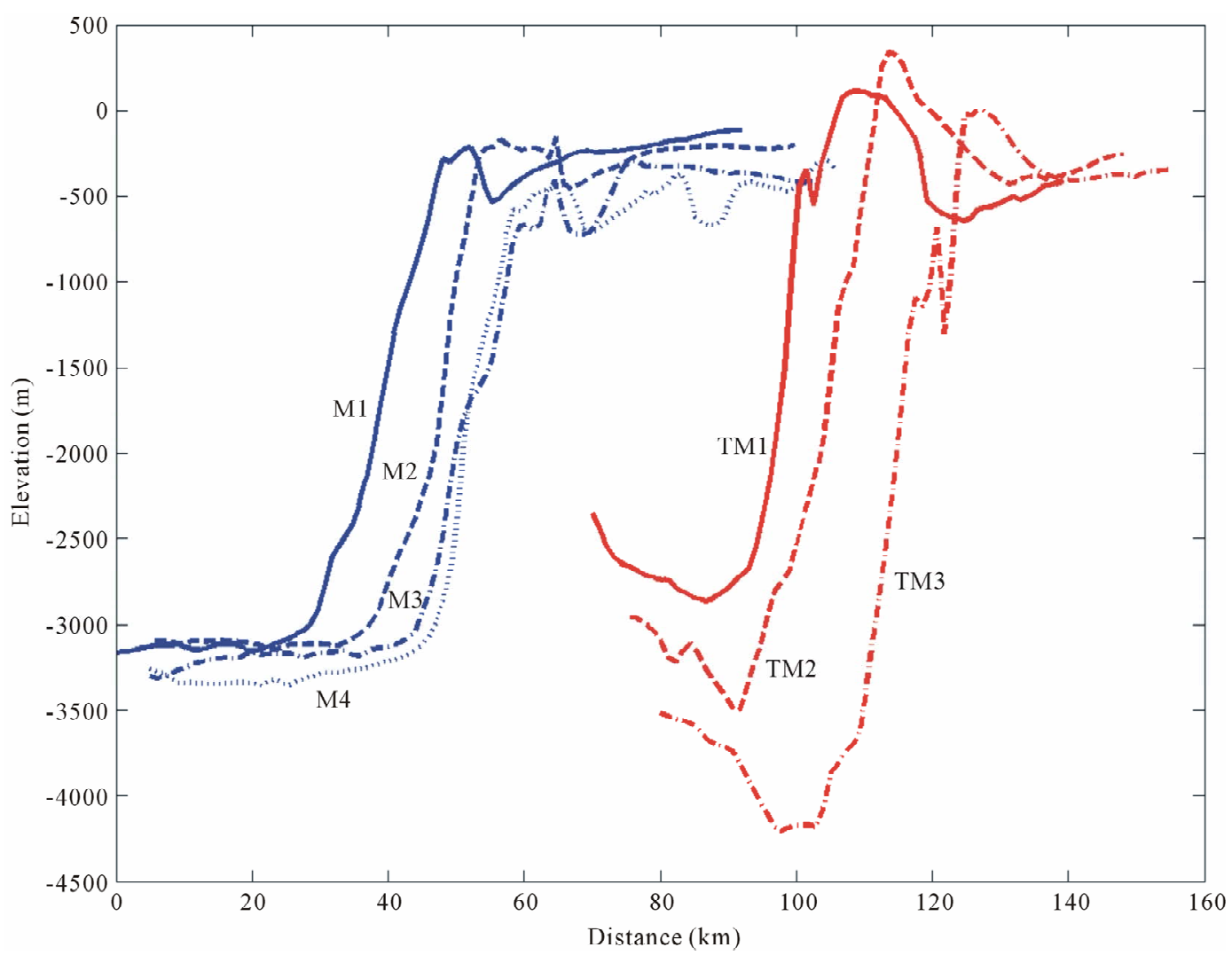

Figure 7. Locations of four topographic profiles (M1-M4) across the Magdalena ocean-shelf transition and three profiles along the Tres Marías Escarpment (TM1-TM3) are shown in Figure 1. The profiles show the topographic similitude between them, supporting the proposition that they were contiguous before separation of Baja California from mainland Mexico. In the former group the shelf is quite shallow while in the latter the shelf appears to have been warped and uplifted, thus forming the islands.

abandoned, left-lateral shearing along the T-A-B channel must have appeared, since the active portion of the trench thrusted against the continent while the abandoned portion did not. As the peninsula moved away towards the $\mathrm{NW}$, thrusting persisted along the terminus of the active trench inducing NE displacement of the TMI fragment, which to the present has accumulated $\sim 106 \mathrm{~km}$ at the terminus of the trench. The motion trajectories for points on the Rivera plate between Chrons 4n.2 and 3n.4 tend to support the block displacements proposed in here. Seismicity NW of Bahía de Banderas decreases markedly with respect to that observed along the Jalisco block [18]; however, episodic events in that region indicate that activity is still present. The 1948 seismic event $\left(M_{w} 6.4\right)$ [35] with epicenter at the base of the Tres Marías escarpment $\left(21.6^{\circ} \mathrm{N}, 106.7^{\circ} \mathrm{W}\right)$ shows that motion is presently to the NE, in agreement with two smaller magnitude earthquakes located also on the TME that occurred in 1976 and 2007. It is worth noticing that in retrospective, the detailed marine contour map of the terminus of the MAT by Fisher [6] already suggested that the transition of the trench south of Cabo Corrientes to Tres Marías Islands could be approximated by a group of en echelon sectors.

\section{Acknowledgements}

This work was supported by PAPIIT-UNAM Grants IN111110-1, IN111110-2, IN100912-1, and IN100912-2.

\section{REFERENCES}

[1] D. Karig and W. Jensky. "The Proto-Gulf of California," Earth and Planetary Science Letters, Vol. 17, No. 2, 1972, pp. 169-174. doi:10.1016/0012-821X(72)90272-5

[2] L. Ferrari, E. Pasquaré, S. Venegas, D. Castillo and F. Romero, "Regional Tectonics of Western Mexico and Its Implications for the Northern Boundary of the Jalisco Block," Geofísica Internacional, Vol. 33, No. 1, 1994, pp. 139-151.

[3] D. G. Moore and J. R. Curray, "Geologic and Tectonic History of the Gulf of California," In: J. R.Curray, D. G. Moore, et al., Eds., Initial Reports of the Deep Sea Drilling Project, US Government Printing Office, Washington DC, 1982, pp. 1279-1294.

[4] J. M. Stock and K. V. Hodges, "Pre-Pliocene Extension around the Gulf of California and the Transfer of Baja California to the Pacific Plate,” Tectonics, Vol. 8, No. 1, 
1989, pp. 99-115. doi:10.1029/TC008i001p00099

[5] M. Lyle and G. E. Ness, "The Opening of the Southern Gulf of California,” In: J. P. Dauphin and B. R. T. Simoneit, Eds., The Gulf and Peninsular Province of the Californias, Memoir 47, AAPG, 1991, pp. 403-423.

[6] R. L. Fisher, "Middle America Trench: Topography, and Structure," Geological Society of America Bulletin, Vol. 72, 1961, pp. 703-720. doi:10.1130/0016-7606(1961)72[703:MATTAS]2.0.CO;2

[7] G. E. Ness and M. W. Lyle, "A Seismo-Tectonic Map of the Gulf and Peninsular Province of the Californias,” In: J. P. Dauphin and B. R. T. Simoneit, Eds., The Gulf and Peninsular Province of the Californias, Memoir 47, AAPG, 1991, pp. 71-78.

[8] K. D. Klitgord and J. Mammerickx, "North East Pacific Rise: Magnetic Anomaly and Bathymetric Framework," Journal of Geophysical Research, Vol. 87, No. B8, 1982, pp. 6725-6750. doi:10.1029/JB087iB08p06725

[9] P. B. Gans, "Large-Magnitude Oligo-Miocene Extension in Southern Sonora: Implications for the Tectonic Evolution of Northwest Mexico,” Tectonics, Vol. 16, No. 3, 1997, pp. 388-408. doi:10.1029/97TC00496

[10] P. J. Umhoefer, "Why Did the Southern Gulf of California Rupture so Rapidly?-Oblique Divergence across Hot, Weak Lithosphere along a Tectonically Active Margin,” GSA Today, Vol. 21, No. 11, 2011.

[11] R. Larson, H. Menard and S. Smith, "Gulf of California: A Result of Ocean-Floor Spreading and Transform Faulting," Science, Vol. 161, No. 3843, 1968, pp. 781-784. doi:10.1126/science.161.3843.781

[12] R. G. Gastil, G. Morgan and D. Krumenacher, “The Tectonic History of Peninsular California and Adjacent Mexico,” In: W. G. Ernst, Ed., The Geotectonic Development of California, Englewood Cliffs, 1981, pp. 285-306.

[13] J. C. Crowell, "Juncture of San Andreas Transform System and Gulf of California Rift,” Oceanologica Acta, Supplement, Vol. 4, 1981, pp. 137-141.

[14] R. S. Yeats and B. U. Haq, "Deep-Sea Drilling off the Californias: Implications of Leg 63,” In: R. S. Yeats, B. U. Haq, et al., Eds., Initial Reports of the Deep Sea Drilling Project, US Printing Office, Washington DC, 1981, pp. 949-963.

[15] W. R. Dickinson, “OVERVIEW: Tectonic Implications of Cenozoic Volcanism in Coastal California,” Geological Society of America Bulletin, Vol. 109, No. 8, 1997, pp. 936-954. doi:10.1130/0016-7606(1997)109<0936:OTIOCV >2.3.C $\underline{\mathrm{O} ; 2}$

[16] G. A. Rusnak, R. L. Fisher and F. P. Shepard, "Bathymetry and Faults of Gulf of California,” In: T. H. van Andel and G. C. Shor Jr., Eds., Marine Geology of the Gulf of California, American Association Petroleum Geologists, Tulsa, 1964, pp. 59-75.

[17] T. Atwater and J. Stock, "Pacific-North America Plate Tectonics of the Neogene Southwestern United States: An update,” In: C. A. Hall, C. A. Nelson and W. G. Ernst, Eds., Integrated Earth and Environmental Evolution of the Southwest: The Clarence A. Hall, Jr. Volume, Geo- logical Society of America, 1998, pp. 393-420.

[18] M. Pardo and G. Suárez, "Shape of the Subducted Rivera and Cocos Plates in Southern Mexico: Seismic and Tectonic Implications,” Journal of Geophysical Research, Vol. 100, No. B7, 1995, pp. 12357-12373. doi:10.1029/95JB00919

[19] J. E. Spencer and W. R. Normark, "Tosco-Abreojos Fault Zone: A Neogene Transform Plate Boundary within the Pacific Margin of Southern Baja California, Mexico," Geology, Vol. 7, 1979, pp. 554-557. doi:10.1130/0091-7613(1979)7<554:TFZANT>2.0.CO;2

[20] C. DeMets and S. Traylen, "Motion of the Rivera Plate Since 10 Ma Relative to the Pacific and North American Plates and the Mantle,” Tectonophysics, Vol. 318, No. 1-4, 2000, pp. 119-159. doi:10.1016/S0040-1951(99)00309-1

[21] J. R. Curray, D. G. Moore, D. Kelts and G. Einsele, “Tectonics and Geological History of the Passive Continental Margin at the Tip of Baja California,” In: R. S. Yeats, B. U. Haq, et al., Eds., Initial Reports of the Deep Sea Drilling Project, US Printing Office, Washington DC, 1981, pp. 1089-1116.

[22] J. Arzate, R. Alvarez, V. Yutsis, J. Pacheco and H. López-Loera, "Geophysical Modeling of Valle de Banderas Graben and Its Structural Relation to Bahía de Banderas, Mexico,” Revista Mexicana de Ciencias Geológicas, Vol. 23, No. 2, 2006, pp. 184-198.

[23] R. Alvarez, "Submarine Topography and Faulting in Bahía de Banderas, Mexico,” Geofísica Internacional, Vol. 46, No. 2, 2007, pp. 93-116.

[24] P. Lonsdale, "Structural Patterns of the Pacific Floor Offshore of Peninsular California,” In: J. P. Dauphin and B. R. T. Simoneit, Eds., The Gulf and Peninsular Province of the Californias, Memoir 47, AAPG, 1991, pp. 87-125.

[25] J. M. Fletcher, M. Grove, D. Kimbrough, O. Lovera and G. E. Gehrels, "Ridge-Trench Interactions and the Neogene Tectonic Evolution of the Magdalena Shelf and Southern Gulf of California: Insights from Detrital Zircon U-Pb Ages From the Magdalena Fan and Adjacent Areas,” GSA Bulletin, Vol. 119, No. 11-12, 2007, pp. 13131336. doi:10.1130/B26067.1

[26] K. M. Marsaglia, "Sandstone Detrital Modes Support Magdalena Fan Displacement from the Mouth of the Gulf of California," Geology, Vol. 32, No. 1, 2004, pp. 45-48. doi:10.1130/G20099.1

[27] J. Mammerickx and K. D. Klitgord, "North East Pacific Rise: Evolution From 25 my B:P. to the Present,” Journal of Geophysical Research, Vol. 87, 1982, pp. 6751-6759. doi:10.1029/JB087iB08p06751

[28] P. Lonsdale, "Segmentation and Disruption of the East Pacific Rise in the Mouth of the Gulf of California," Marine Geophysical Researches, Vol. 17, No. 4, 1995, pp. 323-359. doi:10.1007/BF01227039

[29] R. Alvarez, "Banderas Rift Zone: A Plausible NW Limit of the Jalisco Block," Geophysical Research Letters, Vol. 29, No. 20, 2002, pp. 1994-1997. doi:10.1029/2002GL016089

[30] R. Alvarez, H. López-Loera and J. Arzate, “Modeling the Marine Magnetic Field of Bahia de Banderas, Mexico, 
Confirms the Half-Graben Structure of the Bay," Tectonophysics, Vol. 489, No. 1-4, 2010, pp. 14-28.

doi:10.1016/j.tecto.2010.03.012

[31] R. Reyes-Flores, "Exploración Petrolera en la Plataforma Continental del Pacífico (Edos. Nayarit-Sinaloa),” Ingeniería Petrolera, 1983, pp. 5-20.

[32] R. M. Prol-Ledesma, et al., "Heat Flow Variations along the Middle America Trench,” Marine Geophysical Researches, Vol. 11, No. 1, 1989, pp. 69-76. doi:10.1007/BF00286248

[33] D. Lizarralde, et al., "Variations in Styles of Rifting in the
Gulf of California,” Nature, Vol. 448, 2007, pp. 467-469. doi:10.1038/nature06035

[34] R. P. Von Herzen, "Geothermal Heat Flow in the Gulfs of California and Aden,” Science, Vol. 140, No. 3572, 1963, pp. 1207-1208. doi:10.1126/science.140.3572.1207

[35] S. H. Jaramillo and G. Suárez, “The 4 December 1948 Earthquake (MW 6.4): Evidence of Reverse Faulting beneath the Tres Marías Escarpment and Its Implications for the Rivera-North American Relative Plate Motion," Geofísica Internacional, Vol. 50, No. 3, 2011, pp. 313-317. 